Ilmu Pertanian (Agricultural Science)

Vol. 3 No. 1 April, 2018 :12-20

Available online at http://journal.ugm.ac.id/jip

DOI: doi.org/10.22146/ipas.34594

\title{
Dynamics of Storage Materials in Cotyledon during Cocoa Seed Germination
}

\author{
Sakiroh $^{1,2 *}$, Taryono ${ }^{1}$, Setyastuti Purwanti ${ }^{1}$ \\ ${ }^{1}$ Faculty of Agriculture, Gadjah Mada University, Bulaksumur, Yogyakarta 55281 \\ Jln. Flora no. 1, Bulaksumur, Sleman, Yogyakarta 5528, Indonesia \\ ${ }^{2}$ Indonesian Industrial and Beverage Crops Research Institute, Sukabumi, West Java, Indonesia. \\ Jln. Pakuwon Km.2 Parungkuda, Sukabumi, West Java, Indonesia \\ *Corresponding email: saky1605@gmail.com
}

Received: 09th April 2018; Revised: $15^{\text {th }}$ November 2018; Accepted: $06^{\text {th }}$ December 2018

\begin{abstract}
Degradation of carbohydrate, protein and lipid food reserves occurs in the seed germination process to produce energy for germination and further growing. This study aimed to determine dynamics the content of protein, carbohydrates, and lipid in cotyledon of seed clon i.e. Sca 6, RCC 70, RCC 71 and KKM 22 during germination. The experiment used completely randomized design consisted of four replications with 4 treatments. In each cocoa germination phases i.e. before germination, phase II (bend/curved phase), cotyledon emergence, leaves emergence and fall of cotyledon from the sprouts were observed to collect data. This observation were water content, ash content, lipid, soluble protein, total protein and carbohydrate content. The results of the experiment showed that during germination, there was an increasing of water content in cotyledon from the bend phase to the leaf emergence and decrease in the phase of fall of cotyledon The highest water content was observed in the leaf emergence phase as high as $69.42 \%$. The content of ash content, dissolved protein, total protein and carbohydrates in cotyledon fluctuated during the bend phase until the leaf emergence and increased in the phase of fall of cotyledon. Lipid content has decreased from the bend phase until the fall of cotyledons. Carbohydrate levels increased from the bend phase to the fall of cotyledons. The speed of degradation procces of seed stored material (water, lipid, protein and carbohydrate content) during germination was affected by differences in seed clones. The Scavina 6 and KKM 22 clones entered the bend phase and the realease of cotyledon.
\end{abstract}

Keywords: Carbohydrate, fall of cotyledon, lipid, protein, water content.

\section{INTRODUCTION}

Cocoa is one of the estate crop commodities that have an important role in the Indonesian economy. Aside from being a country's foreign exchange contributor, other roles are rural employment providers, farmers' income sources, domestic industry supply providers, and sources of regional economic growth. Until 2014, the area of Indonesia's cocoa plantation has reached $1,727,437$ ha, with production reaching 728,414 tons of dry cocoa beans (Anonymous, 2015). Data of The International Cocoa Organization (ICCO) stated that in 2014, Indonesia was the third largest cocoa seed producer in the world after Ivory Coast and Ghana (Anonymous, 2016).

Several factors affecting cocoa yield and quality i.e. the genetic properties of planting materials, cultivation methods, postharvest handling, and environmental or land suitability factors. Environmental limiting factors in cocoa growth requirements are closely related to soil factors, such as altitude, topography, drainage, soil type, soil physical properties, and soil chemical properties (Rubiyo and Siswanto, 2012).

The effort to improve cocoa yields can be done through rejuvenation with good quality seed provision that includes physical, genetic and physiological quality. The planting material is the fundamental source to achieve high yield. Cocoa propagation can be done by cuttings or grafting (vegetative) or using seeds (generative). One of the obstacles in the provision of cocoa seeds is its characteristics as recalcitrant seeds that are not dry-resistant seeds, sensitive to temperature and low humidity (Saleh, 1994). Naturally cocoa seeds do not have dormancy, the seeds cannot 
stored for long time and sensitive to changes in the storage environment. One of causes of high and low quality seed is determined by the seed size. One of the seed technologies to overcome the problem of cocoa seeds is synthetic seeds. Benefits of Synthetic seed technology are long period storage, simplify the process of seed distribution, and could protect seeds from pests and diseases (Muslihatin et al., 2016). One of the ways to develop synthetic seeds in cocoa by find out the dynamics of cotyledon stored materials on germination phase at different seed sizes to determine the nutritional needs on seed sprout/seedling.

Seed size is related to seed viability and vigor because the heavier and the bigger seeds have better germination speed and improved seed development. The previous studies illustrated that for certain species, large seeds had better quality than small seeds. Large seeds of Shorea leprosula $(1.4-1.7 \mathrm{~cm}$ long and $0.9-1.20 \mathrm{~cm}$ in diameter) result in better germination, higher growth, and wider seedling diameter compared to small seeds $(0.7-0.99 \mathrm{~cm}$ long and $0.63-0.80 \mathrm{~cm}$ in diameter) (Rayan and Cahyono, 2011). The growth rate of maize sprouts increased with the larger seed size (Gusta et al., 2003).

The role of seeds as a planting material, then the chemical composition of seeds should be known. The chemical composition of seeds is greatly affected by genetics, cultivation and environmental factors. Most seeds contain two or more food reserves in sufficient quantities, which are synthesized during the development of seeds. The main food reserves of the seeds are carbohydrates, proteins and lipids.

The degradation of carbohydrate, protein and lipid occurs during germination in order to produce energy. The energy result will be used to germinate and to grow. The degradation of food reserves for each compound is through the enzymatic process. The results of the degradation of food reserve in the form of simple carbohydrate compounds are transferred to the growing point so that it can be used as an energy source for growth (Widjayanti et al., 2013). According to Lehrian and Patterson (1983), in the germination phases of cocoa beans, there was a decrease of seed components such as lipid, carbohydrate and protein by enzyme activity. The findings of Permana et al. (2013) during germination, an increase in water content was found, while the lipid content and seed weight decreased and dissolved protein content fluctuated but always higher than before germination.

The information of the chemical composition of the seeds of some cocoa clones with different seed sizes and their degradation is important in the development of synthetic seeds. Therefore, it was necessary to conduct an experiment to know the chemical composition of the seeds and their dynamics during germination to produce uniform seedlings, simultaneously grown, and showed uniform performance in the field. This study aimed determine dynamics of the content of protein, carbohydrates, and lipid in cotyledon of Sca 6, RCC 70, RCC 71 and KKM 22 during germination.

\section{MATERIALS AND METHODS}

The study was conducted from January to March 2017 at the glasshouse of Faculty of Agriculture Gajah Mada University (GMU); Laboratory of Plant Sciences, Faculty of Agriculture GMU; and Laboratory of Food and Nutrition, Faculty of Agricultural Technology GMU (analysis of protein, carbohydrates and lipid).

The experiment used completely randomized design (CRD) consisted of four replications with 4 treatments. The treatments were 4 cocoa i.e. clones with Sca 6 , KKM 22, RCC 70 and RCC 71). All seeds were originally obtained from PT. Pagilaran in Segayung, Batang, Central Java

Before germinating, cocoa fruit were separated between its seeds and flesh and then was extracted using rice husk ash to remove the pulp that wrapped the seeds and washed with tap water and drained. After that, the seeds were germinated in well-sieved sand media. For each treatment, 100 seeds planted with spacing $4 \mathrm{~cm} \mathrm{x} 4 \mathrm{~cm}$ and 4 replications, so the required seed was 1,600 seeds. Watering was done every day by using manual spray (hand sprayer).

The analysis includes of water content using gravimetric method (AOAC, 1995 ), ash (AOAC, 1990), lipid (AOAC, 1995), soluble protein (Lowry, 195 in Sudarmadji, 2007), total protein (AOAC,1970), and carbohydrate (by different) (Winarno, 1986) in cotyledon was done on seeds before and after germination of namely: germination Phase II/bend phase, opening cotyledons, leaves emergence (4 to 5 leaves), and fall of cotyledon (Figure 1). The experimental unit consisted of 4 replicates and 4 cocoa clones of different seed sizes so that the total experiment unit was 16 . The analysis results were presented in graph.

\section{Determination of the water content}

Water content was determined gravimetrically according to the Association of Official Analytical Chemists (AOAC, 1995). Samples dried in controlled oven to gained constant weight. Two grams $(2.0 \mathrm{~g})$ of the sample was accurately weighed on the porcelain. The porcelain with its content was put into the oven 


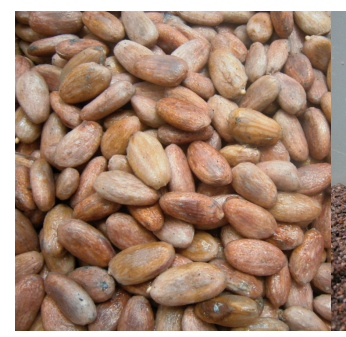

(A)

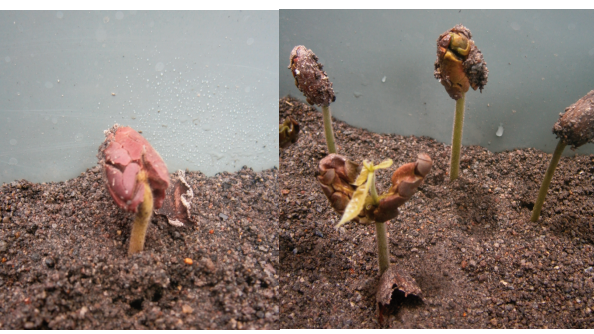

(B)
(C)

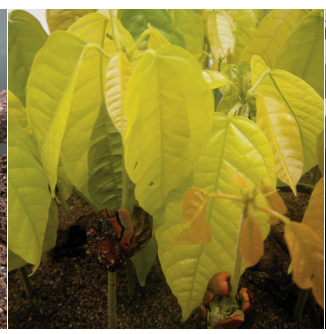

(D)

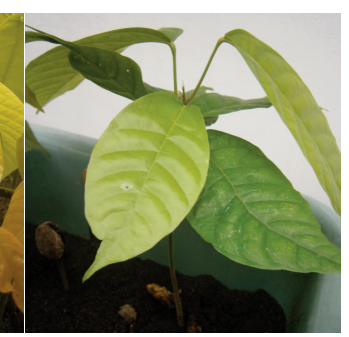

$(\mathrm{E})$

Figure 1. Germination phase (A) before germination, (B) phase II / bend phase, (C) cotyledon opening, (D) leaves emergence and (E) fall of cotyledon.

at $105^{\circ} \mathrm{C}$ for $24 \mathrm{~h}$. Then the sample was cooled in a desiccator and weighed. The loss in weight expressed as a percentage of the initial weight of the sample gives the moisture content of the sample.

\section{Determination of the ash content}

Ash was determined by the method of Association of Official Analytical Chemists (AOAC, 1990). A $2.0 \mathrm{~g}$ sample was weighed into a previously dried and weighed porcelain crucible. The crucible with its content was placed in a furnace preheated to $600^{\circ} \mathrm{C}$ for $2 \mathrm{~h}$. The sample was allowed to cool in the furnace to $250^{\circ} \mathrm{C}$. The crucible and the ash were then transferred into an oven at $100^{\circ} \mathrm{C}$ for $30 \mathrm{~min}$ cooling. After this period, the crucible with its content was cooled in a desiccator. The crucible with its content was weighed. The weight of the ash was expressed as a percentage of the initial weight of the sample.

\section{Determination of the lipid content}

Lipid content was determine using soxhlet (AOAC, 1995). The crude fat was extracted from 1-2 $\mathrm{g}$ of each sample using Soxhlet extractor in low boiling point $\left(40-60^{\circ} \mathrm{C}\right)$ of petroleum ether. The weight of the lipid after solvent evaporating presented the weight of the lipid.

$$
\% \text { Lipid }=\frac{\text { Weight of extract }}{\text { Weight of dry sample }} \times 100
$$

\section{Determination of the soluble protein}

Determination of the dissolved protein content of cocoa seed using the lowry method (Lowry, 1951 in Sudarmadji, 2007). Preparation of Reagent A, $100 \mathrm{~g}$ $\mathrm{Na}_{2} \mathrm{CO}_{3}$ was dissolved in $0.5 \mathrm{~N} \mathrm{NaOH}$ to reach a volume of $1000 \mathrm{~mL}$. Reagent $\mathrm{B}, 1 \mathrm{~g} \mathrm{CuSO}_{4} .5 \mathrm{H}_{2} \mathrm{O}$ was dissolved in distilled water until it reached a volume of $100 \mathrm{~mL}$. Reagent $\mathrm{C}, 2 \mathrm{~g} \mathrm{~K}$-tartrate dissolved in distilled water until it reaches a volume of $100 \mathrm{~mL}$ (reagents A, B, and C could be stored after being prepared before use). Standard bovine serum albumine (BSA) solution of $0.3 \mathrm{mg} \mathrm{mL}^{-1}: 0.08 \mathrm{~g}$ BSA was dissolved in $0.01 \mathrm{M}$ citrate buffer solution of $\mathrm{pH} 6$ which had been cooled at $\pm 10^{\circ} \mathrm{C}$ for 24 hours to reach a volume of $100 \mathrm{~mL}$. Reagent $\mathrm{D}$ was mixed with $15 \mathrm{~mL}$ of reagent A with $0.75 \mathrm{~mL}$ of reagent $B$ and $0.75 \mathrm{~mL}$ of reagent $\mathrm{C}$, then shaken out until homogeneous (reagent $\mathrm{D}$ must be prepared just before use). E reagent: $5 \mathrm{~mL}$ of Folin-Ciocalteu reagent was diluted with distilled water until it reached a volume of $50 \mathrm{~mL}$.

The initial stage of the dissolved protein standard curve on the standard curve prepares BSA $(0 ; 0.06$; $0.12 ; 0.18 ; 0.24 ; 0.30 \mathrm{mg} / \mathrm{mL}$ ) with the aim of creating a support point on the standard curve. Prepared 6 test tubes with a concentration of $0 ; 0.06 ; 0.12 ; 0.18$; $0.24 ; 0.30 \mathrm{mg} / \mathrm{mL}$. Then $1 \mathrm{~mL}$ of reagent $\mathrm{D}$ was added, vortexed and allowed to stand for 15 minutes. Subsequently added $3 \mathrm{~mL}$ of reagent $\mathrm{E}$, unsorted and allowed to stand for 45 minutes. Its absorption is measured at its optimum wavelength. The standard equation for dissolved protein: $\mathrm{y}=\mathrm{BX}+\mathrm{A}$, where $\mathrm{y}$ is the absorbance at $\lambda=750 \mathrm{~nm}$ and $\mathrm{X}$ is the standard dissolved protein concentration, BSA $(\mathrm{mg} / \mathrm{mL})$.

\section{Determination of the total protein}

The total protein content was determined using micro Kjeldahl (AOAC, 1970) by weighing 50-60 $\mathrm{mg}$ or $0.2-0.5 \mathrm{~g}$ of dry matter and placed it in a 50 $\mathrm{ml}$ kjeldahl flask and adding $2 \mathrm{ml} \mathrm{H}_{2} \mathrm{SO}_{4}(93-98 \%$ free $\mathrm{N}$ ). Add $0.5-2 \mathrm{~g}$ of $\mathrm{Na}_{2} \mathrm{SO}_{4}: \mathrm{HgO}$ mixture (20 $\mathrm{g}: 1 \mathrm{~g}$ ) for the catalyst. Heat it in the smoke room until it's clear and continue boiling for another 30 minutes. After cold, wash the wall in the kjeldahl flask with distilled water and boil again for 30 minutes. After cold, add 5-10 $\mathrm{ml}$ of aquadest and add 6-15 $\mathrm{ml}$ of $\mathrm{NaOH}-\mathrm{Na}_{2} \mathrm{~S}_{2} \mathrm{O}_{3}$ solution ( $40 \mathrm{ml}: 5 \mathrm{~g}$ ) and dilute with distilled water to $100 \mathrm{ml}$. Then distillate with kjeldahl microstructure, distillate is stored in erlenmeyer which has been filled with $5 \mathrm{ml}$ of $4 \%$ boric acid (saturated) and given an indicator of a mixture of methyl red-methyl blue or methyl red-bromine (cresol green). Distillation is terminated when all $\mathrm{N}$ is distilled, i.e the droplets are not base. Citrate the distillate with $0.02 \mathrm{~N} \mathrm{HCl}$. Calculate the total $\mathrm{N}$ or protein in ingredients. 


\section{Determination of the carbohydrate content}

Total percentage carbohydrate was determined by the different method as reported by Winarno (1986). The calculation was substract $100 \%$ with added valuae of the total values of percentage of water content, ash, total protein and lipid of the sample.

\section{RESULT AND DISCUSSION}

\section{Water content}

This observation figure 2 showed that water content of all germinated clones increased from the pregermination phase (46.63-48.97\%) to leaf emergence phase (66.44-71.36\%). The phase of fall cotyledon occurred a decrease in water content (38.82-41.54\%), because the cotyledons withered and separated from the germinate.

The initial process of germination is an imbibition process where the water enters into the seed, so that the water content in the seed reaches a certain percentage (between 50 to 60\%) (Permana et al., 2013; Pancaningtyas et al., 2014). In research of Mundo et al. (2015), the water content of cotyledon of cocoa criollo increased at age $0-15$ days after germination.

The increase in water content was caused by the absorption of water from growing media. Increasing water content was caused by water absortion from growing media. Generaly the amount of water absortion was not more than two to three of seed weight. Then the water was used to metabolize and degradate food reserves during germination process.

In contrast to the research of Motilal et al. (2003) that reported that moisture content of cocoa T. cacao var M8 (Amelonado type) in the cotyledon phase fell from 38-48 days germination after germination, from 64.5 to $63.1 \%$. Water absorption by seeds vary between species (Alvarado and Bradford, 2002).

The water content of seeds affected the degradation of carbohydrate, starch, lipid and protein reserves dissolved in cotyledons (Ataíde et al., 2013). In addition, water is needed for the formation of gibberellic acid in seed germination. Gibberellic acid is a hormone that stimulates the activation of metabolic enzymes such as lipase, protease and amylase (Debeaujon et al., 2007).

\section{Ash Content}

According to Figure 3, the ash content of all clones from the pre-germination phase to the opening phase of cotyledon tended to be between $4.51-5.74 \%$, then decreased at the leaf emergence phase, and increased again in the phase of fall of cotyledon (Figure 3). The ash content of Sca 6, KKM 22, RCC 70 and RCC 71 in the fall of cotyledon phase was higher than the previous phase. The highest ash content in the fall of cotyledon phase was found in KKM 22 cotyledon. High ash content showed a high mineral content in cotyledons.

Ash content is the residual inorganic substance of combustion of an organic material present in cotyledon. The same amount of ash content at the pre-germination phase to the opening phase of cotyledon was suspected to occur because the need for inorganic compounds was not much at those phases, so that ash content at different germination ages remained unchanged (Anggrahini, 2007), while the low ash content in the leaf emergence phase was due to the need for more organic matter. The fall of cotyledon phase was higher than the previous phase. In the opinion of Pranoto et al. (1990), after the sprouts developed and were able to produce their own food to grow, it gradually became less dependent on food reserves of storage tissues.

\section{Lipid}

The results of this present study which used ripe seeds contained less than $40 \%$ lipid content were as follows: Sca 6 (47.04\%), KKM 22 (45.53\%), RCC 70 ( 46.50\%) and RCC 71 (44.68\%). The lipid content of Sca 6, KKM 22, RCC 70 and RCC 71 decreased during germination, but there were differences

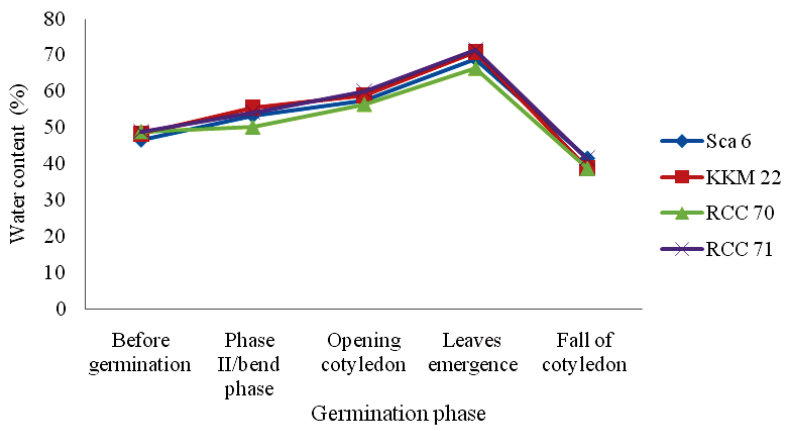

Figure 2. Changes in cocoa cotyledon content in the germination phase

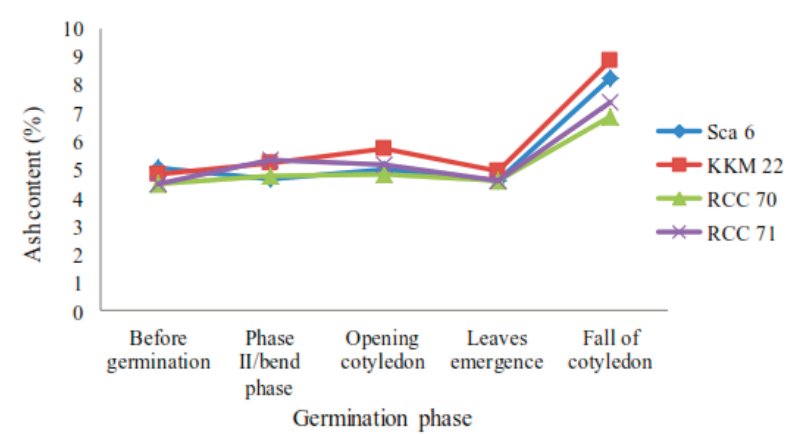

Figure 3. Changes of ash content of cocoa cotyledon in the germination phase 


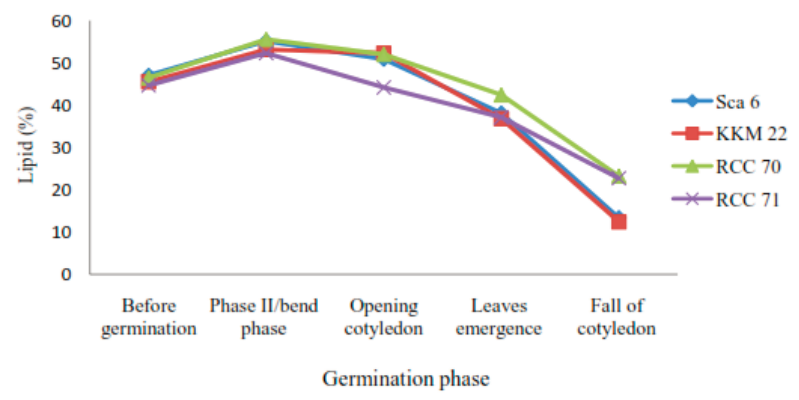

Figure 4. Changes of lipid content in cocoa cotyledon in the germination phase

among several clones in the phase after the fall of cotyledons. In the phase after the fall of cotyledons, the Sca 6 and KKM 22 most lower lipid content than RCC 70 and RCC 71 (Figure 4).

Lipid content in cocoa seeds began to increase in the fruit maturation phase, while the lipid content in the germination phase decreased again (Permana et al., 2013). It was proven from the results of research on clones ICS 95 and KKM 4 had an increase in protein and lipid content at age 90,110 and 130 after anthesis (Voigt et al., 1995). The bulk cocoa with yellow color on the whole surface of the fruit contained $51.10 \%$ lipid, while in the cocoa with yellow in the groove of fruit, fruit groove back and old yellow maturity level on the entire surface of the fruit had the lipid content of 35.30-36.61\% in dry seed (Marwati et al., 2012). While the results of research of Martini et al. (2008), the lipid content of dry cocoa seed was $49.24 \%$. In fact, the wet cocoa seeds contained about $30-32 \%$ lipid or $50 \%$ in dry beans (Permana et al., 2013).

The decreasing fatty acids was due to lipase activity that hydrolyzed lipid to fatty acids and glycerol (Permana et al., 2013). Lipid hydrolysis will continue to fulfill the required energy and components needed for growth during germination such as the emergence of radicles of cotyledon, growth and development of

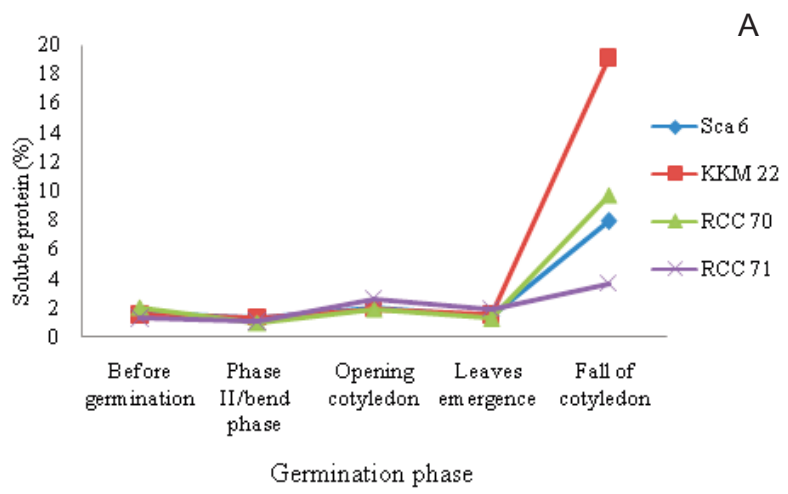

sprouts (Davies and Slack, 1981; Lehrian and Patterson, 1983; Debeaujon et al., 2007; Ataíde et al., 2013).

\section{Soluble protein and total protein}

The content of dissolved protein showed fluctuation in all clones during the germination phase (Figure 5.A). The highest change of dissolved protein content was in the phase of fall of cotyledon which was a sharp increase especially in cocoa seeds of KKM 22. This was in accordance with the statement of Permana et al. (2013) that the dissolved protein of cocoa seeds during germination fluctuated but the content was always higher than before germination. This opinion It was also supported by the research of Doman et al. (1982) using cotton seed (Gossypium hirsutum, cv Deltapine 61) showed that there was an increase in the content of dissolved protein at 24 hours after germination and decreased after 48 hours after germination. In line with the research by Kesari and Rangan (2011), he fluctuation of soluble protein content in the seeds of malapari plants (Pongamia pinnata) occurred on 20 days after germination and its content decreased after the next 25 days.

Proteins are polymers of amino acids (Lopez and Escubedo, 1989). During the germination and growth of sprouts, proteins were degraded by proteases (Kim et al., 2011). The protein levels of cocoa seed increased during ripening and decreased during

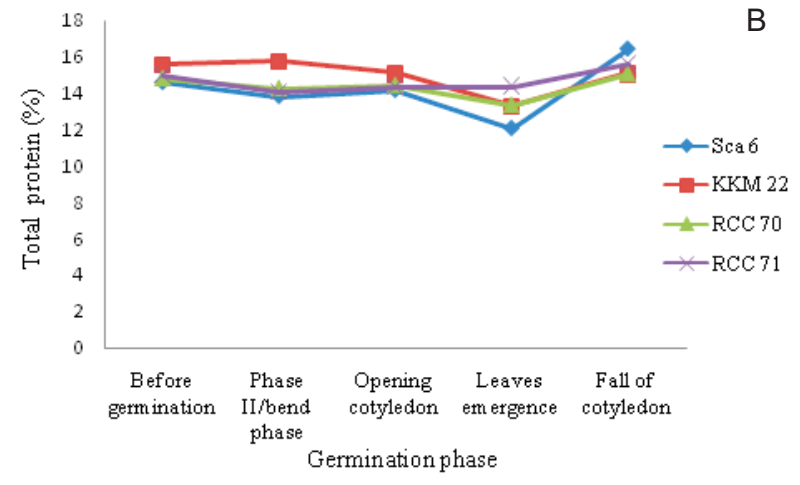

Figure 5. A) Changes in dissolved soluble protein content and B) total protein content of cotyledons 
germination (Biehl et al., 1982). Dissolved proteins are proteins that are easily absorbed by sprouts, whereas total protein is the nitrogen $(\mathrm{N})$ content in cotyledons.

Fluctuations in dissolved protein content occurred because of adjustments in the degradation of proteins during germination. The active protein in the germination process hydrolyzes the protein into shorter chains and amino acids to be converted into energy or components for growth as well. The amino acid aspartate and glutamate in the form of amid will be transferred to the embryo. The amino acid tryptophan will be converted into indole acetic acid (IAA) which triggers growth (Permana et al., 2013). Not only protein breakdown during germination, but there is also a synthesis of amino acids or new proteins that is a necessary for growth.

The total protein content in showed that all cocoa clone seeds have a decrease in total protein content from the phase before sprouting up to the leaf emergence phase and then it increased in the phase of fall of cotyledon (Fig. 5.B). The longer the germination period, the protein content would decrease, because at the time of sprout growth, nitrogen ( $\mathrm{N}$ protein) was used for the formation of new structures as the increasing age in the germination stage (Pertiwi et al., 2013). According to Yudono (2015), a decline in food reserves in cotyledons of corn kernels such as carbohydrates, dissolved proteins, phosphates and nucleic acids was suspected to be translocated into hypocotyl, epicotyl, roots, and plumula.

In contrast to the Pisum sativum L., the total protein content of cotyledons during germination had a slow decline in early germination and increased during the second week after it decreased and remained stable (Guardiola and Sutcliffe, 1971). For Cereus jamacaru plant, total protein content decreased at 12 days after sprouting, but occurred a fluctuated decrease after that (Alencar et al., 2012).

\section{Carbohydrate}

The results observation of Figure 6, all cocoa seed clones had a decrease in carbohydrate content from the germination phase to the bend phase, then the levels continue to increase from the bend phase to the phase of fall of cotyledon. The decreased carbohydrate content was due to the occurrence of carbohydrate hydrolysis into simpler compounds, then used as energy for growth during the germination phase. According to Anggrahini (2007); Hartawan and Nengsih (2012), carbohydrates as food supplies were degraded by the $\alpha$-amylase and $\beta$-amylase enzymes. $\alpha$-Amylase would break down starch into glucose and dextrin while $\beta$-amylase would break starch into maltose and dextrin, which would eventually be converted again to produce energy. Anggrahini research (2007), the carbohydrate content of green bean sprouts decreased during germination process from $66.98 \%$ to $61.70 \%$.

Carbohydrates in the seeds are stored in starch form and the compounds must be hydrolyzed into a simpler compound. There are two pathways in degrading starch which was through the process of amylolysis or hydrolysis and phosphorolysis. The amylolysis process produces glucose, whereas the process of phosphorolysis with the assistance of starch-phosphorylase enzyme, amylose and amylopectin with the help of phosphate ions was degraded to produce glucose and dextrin. Further glucose was transferred to the growing point (root and shoot) (Widjayanti et al., 2013).

Increased carbohydrate levels after the fall of cotyledon might be caused by food reserves were not used anymore. It was thought that sprouts had been able to produce all food to grow and then was gradually no longer dependent on food reserves (Pranoto et al., 1990). The physiological function of cotyledon is to replace the leaf function that has not been activated, so the energy from carbohydrates broke up to produce ATP for growth, especially for leaves. At the time of fall of cotyledon in cocoa, the tissue near the cotyledon

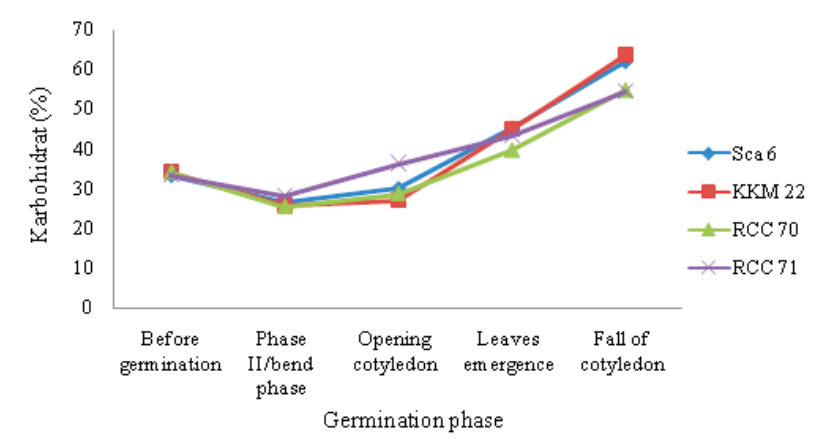

Figure 6. Changes in carbohydrate levels of cocoa cotyledons in the germination phase 
began to have a brownish color and the water content began to fall. According to Du et al. (2014), the old cotyledon would experience discoloration, chloroplast discharge, and degradation of DNA, RNA, and protein. Besides, cotyledon would wither and fell, but the growth of plumula continually increased (Copeland and McDonald, 1985). Meanwhile, according to Haryanti and Budihastuti (2015), polyphenol compounds could trigger the fall of cotyledons from epicotyl. Meanwhile, the phytohormones that affected cotyledon aging were cytokines and ethylene (Ananieva et al., 2008).

There were the differences of material stored content in seed cocoa which were tested before entering germination phase. The highest carbohydrate content was belong to clone RCC 71, while the highest water (48.97\%) and soluble protein $(2.02 \%)$ content were belong to clone RCC 70. Clone Sca 6 was the clone with the highest ash (5.07\%) and lipid (47.04\%) content, whereas clone KKM 22 was the clone with the highest total protein content $(15.60 \%)$. In bend phase, clone KKM 22 was the clone with the highest water content $(55.56 \%)$ and total protein $(15.76 \%)$. The difference in water content is due to differences in the absorption capacity of each clone of water, which indicates that KKM 22 has the ability to absorb higher water. Clone RCC 70 was the clone with the fewest water content (50.24\%). Further clone RCC 71 was the clone with the highest ash content $(5.36 \%)$, whereas clone Sca 6 was the clone with the fewest ash content (4.67\%). Moreover, the highest of lipid (55.57\%) and lowest total protein (0.97\%) content were belong to clone RCC 70 . The result showed that Sca 6 and KKM 22 had faster speed germination on the bend phase which occured at 10 DAP compare to RCC 70 and RCC 71 which enter the bend phase at 12 DAP.

In cotyledons opening phase, all cacao clones had not much different of water content, soluble protein and total protein. The differences was found in lipid and carbohydrate content. Clone RCC 71 had the lowest lipid content (44.20\%) but had the highest soluble protein $(2,61 \%)$ and carbohydrate content $(36.3 \%)$ than three other clones. Each clone had different time in opening cotyledon phase, i.e. Sca 6 (16 DAP), KKM 22 (15 DAP), RCC 70 (19DAP) and RCC 71 (20 DAP).In leaves emergence phase, clone RCC 70 was the clone with the highest lipid content $(42.44 \%)$. This indicated that in seed water and lipid content were more influential factors to speed up the seed entering leaves emergence phase. The time fo leaves emergence phase of Sca 6 was 23
DAP, then followed by KKM 22, RCC 70 and 71 which had the same leaf emergence time at age 27 DAP. In the phase of fall cotyledon, clone KKM 22 was the clone with the highest soluble protein (19.11\%), ash (8.84\%) and carbohydrate (63.30\%) content, while the higest lipid content was belong to clone RCC 70 (23.24\%) and RCC 71 (22.74\%). Time of cotyledon fall from each clone was differnt. The Sca 6 and KKM clones 22 were faster (40 DAP) while the RCC 70 and RCC 71 clones had a longer time to release the cotyledon, i.e. 49 HST. According to Ruiz et al. (2008), the fall of cotyledons occurs when a sprout has a pair of leaves that can photosynthesize to produce energy for growth.

\section{CONCLUSIONS}

During germination there was an increasing of water content in cotyledon from the bend phase until the leaf emergence and decreased in the phase of the fall of cotyledon. The content of ash, lipid, dissolved protein, total protein and carbohydrates in cotyledon fluctuated during the bend phase until the leaf emergence and increased in the phase of fall of cotyledon. Lipid content was decrease from the bend phase to the fall of cotyledon. Carbohydrate levels have increase from the bend phase to the fall of cotyledon. The Scavina 6 and KKM 22 clones entered the bend phase and the fall of cotyledon than the RCC 70 and RCC 71 clones.

\section{ACKNOWLEDGEMENT}

The authors express deep gratitude to Indonesian Agency for Agricultural Research and Development (IAARD), Ministry of Agriculture Indonesia who provided master scholarship at faculty of Agriculture Gajah Mada University. We thank also Indonesian Industrial and Beverage Crops Research Institute.

\section{REFERENCES}

Alencar, N. L. M., R. Innecco, E. Gomes-Filho, M. I. Gallão , J. C. Alvarez-Pizarro, J. T. Prisco and A. B. De Oliveira. 2012. Seed Reserve Composition and Mobilization During Germination and Early Seedling Establishment of Cereus jamacaru D.C. ssp. jamacaru (Cactaceae). An Acad Bras Cienc, 84(3): 823-832.

Alvarado, V. and K.J. Bradford. 2002. A Hydrothermal Time Model Explains The Cardinal Temperatures for Seed Germination. Plant, Cell and Environment, 25 (9): 1061-1071.

Ananieva, K., E.D. Ananiev, S. Doncheva , K. Georgieva, N. Tzvetkova, M. Kamı'nek, V. 
Motyka, P. Dobrev, S. Gajdošova and J. Malbeck. 2008. Senescence Progression in A Single Darkened Cotyledon Depends on The Light Status of The Other Cotyledon in Cucurbita pepo (zucchini) Seedlings: Potential Involvement of Cytokinins and Cytokinin Oxidase/Dehydrogenase Activity. Physiologia Plantaru, 134: 609-623.

Anggrahini, S. 2007. Effect of Germinating Time on The $\alpha$-tocopherol and Proximate Content of Mung Bean Sprout (Phaseolus radiatus L.). Agritech, 27 (4) :152-157.

Anonymous. 2015. Statistik Perkebunan Kakao 2014-2016. Jakarta: Direktorat Jendral Perkebunan.

Anonymous. 2016. Quarterly Bulletin of Cocoa Statistics. Cocoa year 2015/16. Vol. XLII, No. 1. International Cocoa Organization.

AOAC. 1970. Methods of Analysis. Whasingthon D.C: Association of Official Agriculturan Chemists.

AOAC. 1990. Official Methods of Analysis. Washington D.C: Association of Official Analytical Chemist.

AOAC. 1995. Official methods of analysis (16th ed.). Washington D.C: AOAC International.

Ataíde, G.d.M., E. E. D. L. e Borges, J. F. d. C. Gonçalves, V. M. Guimarães, A. V. Flores and E. M. Bicalho. 2013. Alterations in Seed Reserves of Dalbergia nigra ((Vell.) Fr All. ex Benth.) During Hydration. Journal of Seed Science, 35(1): 56-63.

Biehl, B., C. Wewetzer and D. Passern.1982. Vacuolar (Storage) Proteins of Cocoa Seeds and Their Degradation During Germination and Fermentation. Journal of the Science of Food and Agriculture, 33: 1291-1304.

Copeland, L. O. and M. B. McDonald. 1985. Seed Science and Technology Secound edition. Minneapolis: Burgess Publishing Company. $321 \mathrm{p}$.

Davies, H.V and P. T. Slack. 1981. The Control of Food Mobilization in Seeds of Dicotyledonous Plants. New Phytologist, 88: 41-51.

Debeaujon, I. L. Lepiniec, L. Pourcel and J-M. Routaboul. 2007. Seed coat development and dormancy, p 25-49. In: Bradford, K.J. dan Nonogasaki, H. (ed). Seed Development, Dormancy and Germination. Blackwell Publishing. Oxford.

Doman, D. C., J. C. Walker, N.R.Trelease, and B. d. Moore. 1982. Metabolism of Carbohydrate and Lipid Reserves in Germinated Cotton Seeds. Planta, 155:502-510.

Du, J., M. Li , D. Kong, L. Wang, Q. Lv, J. Wang,
F. Bao, Q. Gong , J. Xia and Y. He. 2014. Nitric Oxide Induces Cotyledon Senescence Involving Co-Operation of The NES1/MAD1 and EIN2-associated ORE1 Signalling Pathways in Arabidopsis. Journal of Experimental Botany, 65 (14): 4051-4063.

Guardiola, J.L and J. F. Sutcliffe. 1971. Control of Protein Hydrolysis in The Cotyledons of Germinating Pea (Pisum sativum L.) Seeds. Arm. Bot, 35: 79-807.

Gusta, L.V., E.N. Johnson, N.T. Nesbit and K.J. Kirkland. 2003. Effect of Seeding Date on Canola Seed Vigor. Can. J. Plant Sci., 45: $32-$ 39.

Hartawan, R. dan Y. Nengsih. 2012. Kadar Air dan Karbohidrat Berperan Penting dalam Mempertahankan Kualitas Benih Karet. Agrovigor, 5 (2): 103-112.

Haryanti, S dan R. Budihastuti. 2015. Morfoanatomi, Berat Basah Kotiledon dan Ketebalan Daun Kecambah Kacang Hijau (Phaseolus vulgaris L.) pada Naungan yang Berbeda. Buletin Anatomi dan Fisiolog, 22 (1): 47-56.

Kesari, V. and L. Rangan. 2011. Coordinated Changes in Storage Proteins During Development and Germination of Elite Seeds of Pongamia pinnata, A Versatile Biodiesel Legume. AoB Plants,1-16.http://dx.doi.org/10.1093/aobpla/plr026.

Kim, H. T., U.K. Choi, H.S. Ryu, S. J. Lee and O.S. Kwon . 2011. Mobilization of Storage Proteins in Soybean Seed (Glycine max L.) During Germination and Seedling Growth. Biochimica et Biophysica Acta, 1814: 1178-1187.

Lehrian, D.W. and Patterson, G.R. 1983. Cocoa fermentation. In: Reed, G. (ed). Florida: Biotechnology Vol 5. Verlag Chemie. Weinhim. Lopez, O.P. dan Escobedo, M. 1989. Germination of Amaranth Seeds: Effect on Nutrient Composition and Color. Journal of Food Science, 54: 761-762.

Martini, M.H. C. G.veslenci, A. Figueira and D. D. Q. Tavares. 2008. Localization of The Cotyledon Reserves of Theobroma grandiflorum Willd. ex Spreng.) K. Schum., T. subincanum Mart., T. bicolor Bonpl. and their analogies with $\mathrm{T}$. cacao L. Revista Brasil. Bot, 31 (1): 147-154.

Marwati, H. Suprapto, dan Yulianti. 2012. Effect of Maturity Levels on Cocoa (Theobroma cacao L.) Beans Quality Produced By Cocoa Farmers at Teluk Kedondong, Bayur, Samarinda. Jurnal Teknologi Pertanian, 8 (1): 6-10.

Menteri Kehutanan dan Perkebunan. 1998a. Deskripsi kakao varietas AP 70 Berdasarkan Keputusan Menteri Kehutanan dan Perkebunan. Nomor : 686/Kpts-IX/98. tanggaL : 9 Oktober 
1998. Jakarta.

Menteri Pertanian. 2009. Deskripsi kakao klon Sca

6 Berdasarkan Keputusan Menteri Pertanian.

Nomor : 1984/Kpts/SR.120/4/2009. Jakarta.

Motilal, L.A., G.S. Charran and T.N. Sreenivasan. 2003. Effect of Crinipellis perniciosa Infection on Abscission of Cacao Cotyledons, Reserve Mobilization and Dry Matter Partitioning. J.Phytopathology, 151:546-552.

Mundo, S.M.L., M.X.Quintanilla-Carvajal, C.B.Muńoz, G.F. Gutiérrez-López and M.E.Jaramillo-Flores. 2015. Water Content, aw, and Enzyme Activity (Xaa-Prolyl-Dipeptidyl Aminopeptidase) During The Germination Processof Cocoa Beans (Theobroma cacao L.), p. 533-540. In: NewYork: Water Stress in Biological, Chemical, Pharmaceutical and Food Systems.

Muslihatin, W., N. Jadid, I. D. Puspitasari, and C. E. Safitri. 2016. Growth of Vegetative Explant Moringa oleifera on Different Composition of Auxin and Cytokinin and its Synthetic Seed Germination. in: AIP Proceeding ofInternational Biologi Conference.

Pancaningtyas, S., T.I. Santoso and Sudarsianto. 2014. Studi Perkecambahan Benih Kakao Melalui Metode Perendaman. Pelita Perkebunan 30 (3): 190-197.

Permana, D.G.M., R. Indrati, P. Hastuti, dan Sparmo. 2013. Indogenous Lipase Activities During Cocoa Bean (Theobroma cacao L.). Agritech, 33 (2): 176-181.

Pertiwi, S. F., S. Aminah and Nurhidajah. 2013. Antioxidant Activity, Chemistry Characteristic, and Organoleptic Properties of Sprouts Milk of Black Soybean (Glycine Soja) According to Variation of Time Germination. Jurnal Pangan dan Gizi, 04 (08): 1-8.

Pranoto, H.S, W.Q Mugnisjah and E. Muniarti. 1990. Biologi Benih. Bogor: Institut Pertanian Bogor. 138 p.
Rayan and D.D.N. Cahyono. 2011. Effect of Seed Size From West Kalimantan on Seed Growth of Shorea leprosula in Nursery. Jurnal Penelitian Dipterokarpa, 5 (2): 11-20.

Rubiyo and Siswanto. 2012. Peningkatan Produksi dan Pengembangan Kakao (Theobroma cacao L.) di Indonesia. Buletin Riset Tanaman Rempah dan Aneka Tanaman Industri, 3 (1): 33-48.

Saleh, M.S. 1994. Deteriorasi Biokimiawi dan Benih Kakao Berkecambah Selama Penyimpanan. Agroland, 2 (6):1-5.

Sudarmadji, S., B. Haryono dan Suhardi 1997. Prosedur Analisa untuk Bahan Makanan dan Pertanian. Yogyakarta: Liberty.

Turnbull, C.J. and P. Hadley. 2015. International Cocoa Germplasm Database (ICGD). [Online Database]. CRA td./ICE Futures Europe/University of Reading, UK. Available: http://www.icgd.reading.ac.uk [Accessed 3 October, 2017].

Voigt, J., S. Kamaruddin, H. Heinrichs, D. Wrann, V. Senyuk and B. Biehl. 1995. Developmental Stage-Dependent Variation of The Levels of Globular Storage Protein and Aspartic Endoprotease During Ripening and Germination of Theobroma cacao L. Seeds. J. Plant Physiol, 145 : 299-307.

Widjayanti, E., E. Murniati, E.R., Palupi. T.Kartika, M.R. Suhartono and A. Qadir. 2013. Dasar Ilmu dan Teknologi Benih. Bogor: IPB pers. $173 \mathrm{p}$.

Winarno, F.G. dan S.L. Jenie. 1974. Dasar Pengawetan, Sanitasi dan Peracunan. Departemen Teknologi Hasil Pertanian, Fatemeta, IPB. Bogor.

Yudono, P. 2015. Perbenihan Tanaman Dasar Ilmu, Teknologi dan Pengelolaan. Yogyakarta: Gadjah mada university Press. 308 p. 